\title{
The effect of financial literacy and financial efficacy on individual financial management
}

\author{
Naili Saadah
}

Faculty of Islamic Economics and Business, UIN Walisongo Semarang, Indonesia

\begin{abstract}
Purpose - This study aims to determine the effect of financial literacy and financial efficacy on financial management.

Method - Using mixed methods, namely quantitative and qualitative, this study managed to collect a sample of 307 respondents.

Result - This research provides evidence that the level of a person's financial knowledge can affect his financial management as well as his financial satisfaction, with these results directly this research strengthens the evidence that gender does not affect financial management. it's the habits or behaviors that lead someone to act.
\end{abstract}

Implication - This research can be used to understand behavioral financial management in individual level.

Originality - Many studies show that a society with good financial literacy will have an impact on the formation of a financially independent society. However, the problem here is that there is still discrimination against women regarding financial management. Basically, whether or not they are able to manage finances is not based on gender but on the behavior of the individual. To strengthen this, research is present to prove that individual behavior which includes the level of financial knowledge and financial satisfaction affects their financial management.

Keywords: financial literacy, financial efficacy, financial management, gender 


\section{Introduction}

Having the ability to manage assets is a science that is absolutely necessary for everyone without exception. We will not experience financial difficulties if we are able to make good financial

JIEMB | 80 decisions. All activities in our life are closely related to financial decisions, for example choosing schools for children, choosing savings products, choosing insurance products for individuals and families to making decisions about purchasing assets or investing, all of these things cannot be separated from one's financial literacy.

For every country, financial literacy is considered important to be owned by the community because the higher the financial literacy that is owned by the community will affect the optimal financial decisions taken and affect every social aspect of people's lives. Financial literacy is no different than science that must be studied, the more we learn science, the wiser our decision making will be. As Allah says in Surah Al Mujadalah verse 11:

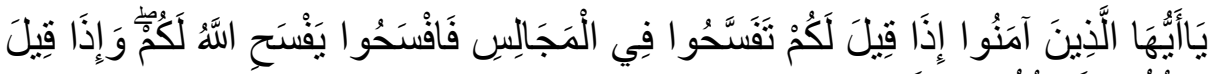

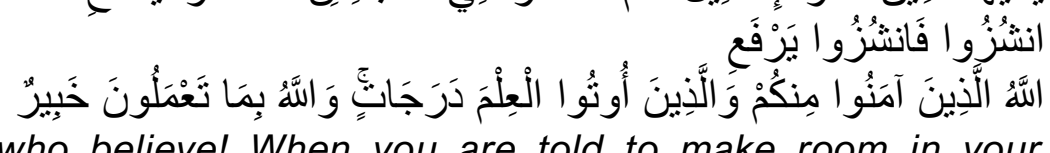
"O you who believe! When you are told to make room in your gatherings, make room; Allah will make room for you. And when you are told to disperse, disperse. Allah elevates those among you who believe, and those given knowledge, many steps. Allah is Aware of what you do"

It is clear that as believers are required to study science, including financial science, so that we are wise in making decisions. documented evidence that education level and income level influence financial management behavior for housewives (Dwiastanti \& Hidayat, 2016). Especially now that the technology era has begun to penetrate the world of finance, so that not only financial knowledge but knowledge of financial technology is also needed.

The entry of technology into the field of financial science does not deny that it can change the behavior pattern of transactions and consumption of the wider community, especially the younger generations today or better known as the millennial generation. Lack of public knowledge about the financial services industry "has resulted in the younger generation being susceptible to contracting 
the diseases of consumerism, hedomism and individualism which emphasize momentary satisfaction and cause prolonged losses. Financial literacy "is not only limited to understanding it but includes its application. . As stated "(Lusardi \& Mitchelli, 2007) in his writing entitled Financial Literacy And Retirement Preparedness: Evidence And Implications For Financial Education Program provides limits on financial literacy or financial literacy as financial knowledge and the ability to apply it."

Several studies have found evidence that demographic factors also influence a person's financial management, one of which is gender. Gender is a biological and physiological difference that can differentiate between men and women (Ariadi, Malelak, \& Astuti, 2015), a characteristic concept that differentiates a person between male and female (Robb \& Sharpe, 2009), and could affect financial literacy (Margaretha \& Pambudhi, 2015). When it comes to comparison between both gender, there is a mixed result for example Mustapha (2015) who stated that men have better financial literacy rates than women (Mustapha, 2015), while Krishna, Rofaida, and Sari (2010) stated the otherwise is applied to context of student.

However, there's also a belief that gender has no effect on financial literacu (Rita \& Pesudo, 2014). Several studies have shown that women and men have different levels of financial literacy, but on the other hand, research conducted by Rita and Pseudo shows that there is no influence between men and women. This difference in results indicates that there are other things that need to be studied more deeply in relation to these differences.

Sina (2013) conducted a study on financial efficacy and financial satisfaction from a gender perspective, where gender is measured by the sexes of men and women, the results of the study prove that women have a higher level of financial satisfaction than men. This result is in contrast to the Satish Kumar which documented the relationship between financial literacy and pension financial planning between men and women where the results of the study proved that women tend to have lower financial knowledge than men after retirement. Woodyard and Robb (2012) also conducted research on gender in relation to financial knowledge which documented evidence that women aged 55-64 are more likely to make financial decisions, but they feel less information related to financial knowledge is different from young women who are not much in making financial decisions. Haque and Zulfiqar (2016a) 
conducted a study similar to research (Kumar et al., 2019) on the effect of financial knowledge. Research results from Haque and Zulfiqar (2016) document that women who work are more able to make decisions related to ideal financial planning because they understand more about financial knowledge than women who do not work. It can be concluded that from several studies that have been conducted on the differences in financial literacy between women and men lies in the courage in making financial decisions and taking risks. This phenomenon reinforces that gender is not only focused on the sex of men and women but individual characteristics that can be owned by all people, both men and women, therefore this study uses gender in the definition (Hofstede, 2011), namely feminism and masculinity. Feminism has different characteristics compared to masculinity. However, the majority of previous studies that have been conducted have only focused on gender differences but do not look at gender characteristics, therefore it is important to conduct research on the effects of financial literacy and financial efficacy on personal financial management from a gender perspective (masculinity and feminism).

\section{Literature review}

\section{Behavioral finance}

The theory of financial behavior began to be echoed in 1969 by Solvic, who stated that there are psychological aspects of individuals related to their financial decisions. This theory is an extension of traditional financial theory. Widayat (2010) in his article explains that traditional financial theory which states that financial decision making is based on rational thinking has been proven empirically but along with the development of the era there are many other factors in decision making not only sourced from rational factors only. Some experts argue that there are psychological factors that influence a person's investment decisions.

This study elaborates on financial literacy on financial management for an individual who is wrapped in a gender cultural dimension. A woman in making financial decisions may have many psychological factors, either because of her marital status, age, income or work. So it is commonly considered that women are not as stable as men. However, it is the same as the behavioral financial theory, this assumption is just an assumption that is not necessarily 
true, because based on the theory that influences a person, his behavior is not the gender.

\section{Financial literacy and financial efficacy}

Finance is an important aspect inherent in people's lives. This is because the financial knowledge possessed can assist individuals in making decisions regarding the determination of financial products that can optimize financial decisions. Financial knowledge is very important for individuals not to make mistakes in making financial decisions later (Margaretha \& Pambudhi, 2015). If their financial knowledge is lacking, it will result in losses for individuals, either as a result of inflation or a decline in economic conditions at home and abroad. Misconceptions cause many people to suffer financial losses, as a result of wasteful spending and consumption, not being prudent in using credit cards, and calculating the difference between consumer loans and bank loans. In addition, a lack of knowledge about finance makes it difficult for someone to make investments or access to financial markets. Lusardi and Mitchell (2014) stated that financial literacy consists of a number of financial skills and knowledge that a person has to be able to manage or use a certain amount of money to improve his standard of life and aim to achieve prosperity.

Achieving financial prosperity or what is commonly called well being is a necessity for everyone. To reach the level of well being is not easy because welfare can not only be measured by the amount of income received but also the ability to manage finances for individuals so that they can achieve both short term and long term welfare. One of the things that can be used as an indicator of financial well-being is financial efficacy or belief in financial management capabilities. Financial satisfaction can be achieved when we have good financial knowledge as stated by Woodyard and Robb (2012) that the level of financial understanding will affect one's financial satisfaction. Self Efficacy was first introduced by (Bandura, 1978). Self-efficacy "is an individual's belief in their ability to organize fibers to carry out an action or action to achieve a desired goal" and "can be linked to a financial context and can be called Financial Self Efficacy". According to Bandura (Bandura, 1978), selfefficacy in each individual will differ from one individual to another. 


\section{Gender in Hofstede cultural dimension}

Gender and sexuality are part of a natural human identity that has received a lot of attention in socio-cultural and political studies. The human male and female are each created with different characteristics or physical traits, some of which are largely identical, while others are different. Gender can be said as an assumption that is formed by culture and environment in terms of the views or beliefs that are formed by society about how a woman or man should behave or think. For example, there is a view that a good and ideal woman must be good at cooking, good at caring for herself, gentle, or a belief that women are sensitive, emotional beings, always prioritizing feelings. On the other hand, a man is often described as having a leadership spirit, assertive as a protector, worthy of being the head of the household, thinking rationally, and so on.

These pictures are characteristics that are formed from the assumptions of society. Answering this question, Hofstede in some of his studies has described gender as an individual character of feminism and masculinity. Masculinity and feminism are cultural dimensions that describe individual behavior related to the distribution of emotional roles between women and men, or it can be said that the psychological characteristics of women who think more about family and avoid risks are reflected in a country with a culture of feminism and vice versa, the characteristics are firm and straightforward and not afraid. risk is owned by the majority of individuals in a country that has a masculine cultural dimension.

\section{Effect of financial literacy on financial management}

Financial literacy or financial literacy is the knowledge a person has about the financial services industry, someone who has high financial literacy is considered a person who is financially "literate". Several studies document evidence that women have lower financial literacy than men, satish kumar (Kumar et al., 2019) which documents the relationship between financial literacy and pension financial planning where the results prove that women tend to have lower financial knowledge than men after retirement. However (Haque, Abdul; Zulfiqar, 2016) documented that women who work are more able to make decisions related to ideal financial planning because they understand more about financial knowledge than women who do not work. 
This difference indirectly proves to us that it is not gender that distinguishes financial management but rather a person's personal characteristics and level of financial knowledge. The better, the better the level of one's financial understanding, it will also have an impact on the better management of one's finances. Based on this explanation, the proposed hypothesis is:

Hypothesis 1: Financial literacy has a positive effect on good financial management

\section{Effect of financial efficacy on financial management}

One of the things that can be used as an indicator of financial well-being is financial efficacy or belief in financial management capabilities. As a woman, she is required to be able to manage finances well on the basis of her financial knowledge. Financial satisfaction can be achieved when we have good financial knowledge as stated by (Woodyard \& Robb, 2012) that the level of financial understanding will affect one's financial satisfaction.

Strengthening these arguments, Hira and Mugenda (1998) state that accuracy in financial management triggers the achievement of financial satisfaction. A person's ability to manage assets is often referred to as financial efficacy. As stated by (Brandon \& Smith, 2009) Financial Effectiveness is a positive belief in the ability to successfully manage money. Therefore, the better the financial self-efficacy, the better it is to manage money appropriately so that the resulting behavior will be better too. Financial efficacy is a positive belief in one's ability to manage finances, the higher the efficacy of a person, the better his financial management is, based on this description, the hypothesis we propose is:

Hypothesis 2: Financial efficiency has a positive effect on financial management

\section{Methodology}

The choice of research type depends on the condition of the object to be studied. This study uses a mixed method between quantitative and qualitative research with empirical studies on people in the city of Semarang. The term "mixed methods" refers to an emerging research methodology that advances the systematic integration, or "blending," of quantitative and qualitative data in one 
ongoing investigation or program of inquiry. The basic premise of this methodology is that such integration allows a more complete and synergistic use of data than the separate collection and analysis of quantitative and qualitative data. Quantitative research methods rely more on positive principles that use variable language and hypotheses (Lawrence, 2013). Quantitative design is used in this study to measure the relationship between the independent and dependent variables, namely financial literacy, financial efficacy and financial management. Meanwhile, to interpret the relationship between the results of statistical data and the echoed gender theory (Hofstede, 2001), qualitative design is used as a complement to this study.

Several stages have been carried out to prove the validity of the data used, including testing the validity and reliability of the instruments used in this study, then followed by testing with multiple linear regression to test the effect between variables used after which reinforce the argumentation of multiple regression results, then the interpretation of the results with study the literature was added as data analysis.

\section{Results and discussion}

\section{Demography of respondents}

A total of 307 respondents were used in this study, referring to the demographic table of respondents above the majority of respondents in this study were women with a percentage of $63.5 \%$ while the rest were men. Then looking at the level of education of the respondents, it can be seen that more than $70 \%$ of respondents have higher education in the sense that they have completed education at the undergraduate and postgraduate level, this shows that the majority of respondents are people who have been well educated or educated people with an average income level in the range figures of IDR 3,000,000 to IDR 6,000,000.

\section{Classical assumption test}

The feasibility of data in a study is absolutely necessary because proper data has an effect on the research results. To prove this, the classical assumption test is necessary. Because the classical assumption test is a test of the feasibility of the data used

Table 2. Demography of respondents 


\begin{tabular}{lcc}
\hline \multicolumn{1}{c}{ Information } & Frequency & Percentage \\
\hline Gender & 112 & \\
Male & 195 & $36,5 \%$ \\
Female & & $63.5 \%$ \\
Education & 30 & \\
Primary school & 103 & $9,8 \%$ \\
Undergraduate degree & 150 & $33,6 \%$ \\
Postgraduate degree & & $48,9 \%$ \\
& & \\
Income & 107 & $34,9 \%$ \\
$1.000 .000-3.000 .000$ & 156 & $50,8 \%$ \\
$3.000 .000-6.000 .000$ & 40 & $13,0 \%$ \\
$6.000 .000-10.000 .000$ & 4 & $1,3 \%$ \\
$>10.000 .000$ & & \\
\hline
\end{tabular}

in a study, which includes three tests, namely the data normality test, heteroscedasticity test and autocorrelation test. Even so with this research which has carried out the classical assumption test with the results presented in Table 2 .

The data normality test is one of the first classical assumption tests performed, where the data normality test is carried out to ensure that the research data is normally distributed. Some literature describes the data normality testing mechanism, one of which is the Kolmogorof Smirnov test. Kolmogorof-Smirnov test results can be seen in the first row of Table 2 showing Asymp. Sig. (2-tailed) is worth 0.000 . This figure means that the residual data is normally distributed. Or it can be concluded that the research data is normally distributed.

Then the next test in the classical assumption test is the multicollinearity test where the multicollinearity test results are presented in rows 2 and 3 in Table 2, the determination of the multicollinearity test uses the basis of the tolerance and vif values where if the tolerance value is more than 0.1 and the vif value is less than 10 then no. multicollinearity occurs. Even so, with the results of this study where the financial literacy and financial efficacy in lines 2 and 3 have a tolerance value of more than 0.1 , namely 0.718 and

Table 2. Result of classical assumption test

\begin{tabular}{lcccc}
\hline \multicolumn{1}{c}{ Information } & $\begin{array}{c}\text { Unstandardized } \\
\text { residual }\end{array}$ & Tolerance & VIF & $\begin{array}{c}\text { Durbin- } \\
\text { Watson }\end{array}$ \\
\hline Asymp. Sig. (2- & $.000^{c}$ & & & \\
tailed) & & 0,718 & 1,392 & \\
Financial literacy & & 0,720 & 1,390 & \\
Financial efficacy & & & & 2,005 \\
Model regresi & &
\end{tabular}


0.720 , while the VIF value is less than 10 , namely 1.392 and 1.390 , therefore the data of this study passed the multicollinearity test.

After going through these two tests, to ensure that the research data is truly feasible, an autocorrelation test is needed, which in this study uses Durbin Watson as the autocorrelation test. The test results are presented in the fourth row in Table 2. You can see the number 2.005 in the table. The value of 2.005 when applied to the $\mathrm{du}<\mathrm{d}<4$-du formula which results in $1.728<2.005<2.312$ or it can be concluded that there is no positive or negative autocorrelation in the regression model. Reading the three classical assumption test results that have been done, it can be concluded that this research data is feasible to use because it has been proven by the classical assumption test.

\section{Result of regression test}

After conducting a series of classical assumption tests to see the influence between the dependent and independent variables in the study, the study conducted multiple regression tests where regression analysis was used to determine the influence of each independent variable on the dependent variable. The F-test and Ttest are used as a series of multiple regression analysis where the test results are presented in Table 3.

Table 3 presents the results of the multiple regression test from this study, the effect of the two independent variables, namely financial literacy and financial efficacy on financial management, is shown in the first row of Table 3. The number 0.000 has a significance value below $0.05 \%$, with details as financial literacy having a significance value of 0.000 , while the financial efficacy variable has a significant value of 0.000 with a positive relationship, so it can be concluded that the dependent variable personal financial management is influenced by the level of financial literacy and financial efficacy with the direction positive effect.

\section{The effect of financial literacy on financial management (H1)}

The first hypothesis states that financial literacy has a positive effect on personal financial management. The result of multiple

Table 3. Result of multiple regression test

\begin{tabular}{lccc}
\hline Information & Sig & Tolerance & vif \\
\hline Regression & 0,000 & & \\
Financaial efficacy & & 0,718 & 1,392 \\
Financial literacy & & 0,720 & 1,390 \\
\hline
\end{tabular}


regression analysis shows that the independent variable of the level of financial literacy has a regression coefficient with a positive sign of 0.000 , which means that the effect of the level of financial literacy on personal financial management is positive.

The T-count value of 1.977 is greater than the T-table value of 1.969 ( $\mathrm{df}=248$ ), and a significance value of 0.049 which is smaller than the degree of confidence ( $\alpha$ ) 0.05 . Thus, the first hypothesis (H1) is accepted, namely that financial management has a positive effect on financial literacy or the level of financial literacy.

The positive effect in this regression model means that the higher or better the management of one's personal finances is influenced by the high level of financial literacy or the goodness of one's financial literacy. Financial literacy or financial literacy is the knowledge a person has about the financial services industry, someone who has high financial literacy is considered a person who is financially "literate".

\section{Effect of financial efficacy on financial management (H1)}

The second regression model has three variables, financial management as the dependent variable and as the independent variable the level of financial efficacy. The second hypothesis in this study states that financial efficacy has a positive effect on financial management. The results of multiple regression analysis show that the independent variable financial efficacy has a regression coefficient with a positive sign of 0.000 , which means that the effect of audit quality on earnings management is positive.

The T-count value of 1,814 is greater than the T-table value of 1.969 ( $\mathrm{df}=248)$, and a significance value of 0,000 which is greater than the degree of confidence ( $\alpha$ ) 0.05 . Thus, the second hypothesis $(\mathrm{H} 2)$ is accepted, which means that financial efficacy has an effect on personal financial management.

The positive influence in this regression model can be interpreted as the better the level of one's satisfaction with their finances has a significant impact on good financial management. One of the things that can be used as an indicator of financial wellbeing is financial efficacy or belief in financial management 
capabilities. As a woman, she is required to be able to manage finances well on the basis of her financial knowledge.

\section{Characteristics of Feminism in Financial Management}

JIEMB | 90 Feminism and masculinity are said by (Hofstede, 2011) as behaviors that are formed as a result of cultural influences which include environment, family, habits, and others. Feminism is a behavior that falls into a gentle tendency and avoids risk, where the majority of feminist behavior is owned by women so that feminism here is often associated with the female gender, and vice versa. Masculinity with a tendency to behavior that is firm and ready to avoid risks is owned by the majority of individuals of the male sex so that masculinity is often associated with the male gender. However, feminism and masculinity are not related to gender. Because gender has the meaning of seeing individuals based on physiological differences in the form of sex, but masculine and feminine see individuals from their behavior.

Islam discusses gender issues as the coexistence of two equal partners, in the sense that each partner complements each other. It is not surprising that the main point of Islam contains several points of inequality between men and women, because there are natural and psycho-cognitive differences between the genders.

There are differences in natural identity, body tenderness, sexual drive and reaction, reproductive function and implications, and hormones. There are also differences in the ability to influence others, in response to stimuli, flexibility, degree of dependence on surrender, acceptance, and concentration. Therefore, once again it is conveyed that gender is no longer defined by men and women but is a behavior that is formed from the environment, where both men and women have the same rights.

The equal position between women and men here proves that the role of women in a family is to be a companion for men who can make up for men's shortcomings. Even so with financial management. The culture in Indonesia characterizes the management of household finances as the authority of women as wives and housewives even though the woman is working or not working.

However, not a few household financial management is held or under the control of men as head of household or husband. This is 
where the evidence is that it is not gender that distinguishes but the abilities or capabilities possessed by the individual where the person's abilities are influenced by the environment and culture. In the dimension of hofstede culture, Indonesia is categorized as a country with feminist and collective cultural characteristics.

The characteristics of feminism characterize the culture and personalities of individuals who avoid risks and plan well for longterm goals. One of the habits of society that can be a special characteristic of feminist characteristics in financial management is that the majority of people invest in fulfilling family needs.

Family needs are a priority in the financial management of the community which is categorized as feminism. This statement is proven by the answers given by the respondents. Where several questions that asked about recording expenses and financial planning had been carried out, both male and female respondents. Respondents 'risk avoidance is reflected in respondents' questions regarding the financial industry, where the most widely used financial institution by respondents is the banking industry.

\section{Conclusion}

Summarizing the discussion of the data analysis that has been carried out in this study, provides some important evidence that based on the results of research and discussion of the effect of the level of financial literacy and the level of financial satisfaction on one's financial management in order to test the theory of financial behavior and financial management and based on objectives. which has been described in chapter one, several conclusions can be drawn.

First, the level of financial literacy has a positive and significant effect on financial management. This result means that the level of financial knowledge proxied by several questions proves that the better one's financial knowledge, the better the financial management method.

Second, financial efficacy or financial satisfaction has a positive and significant effect on financial management. This result indicates that the level of financial satisfaction as proxied by several questions proves that the higher the level of financial satisfaction, the better the financial management method. 
Third, gender and sexuality are part of the natural identity possessed by humans and have been given a lot of attention in various types of studies, especially socio-cultural and political. Several religious studies have contributed to clarifying the positions of various religions on gender-related orders, confirming concepts and interpreting texts that discuss sex. The human male and female are each endowed with a set of characteristics some of which are largely identical, while others have distinguishing characteristics. Certain or identical characteristics of sex differences seem to affect men and women sexually. Men and women have differences with different degrees, but gender which is discussed in Hofstede's dimension is behavior that is formed due to the environment. Where these behaviors can influence impulsively, activities and orientation, as well as gender relations, clothing, rights and a sense of responsibility.

\section{References}

Ariadi, R., Malelak, M. I., \& Astuti, D. (2015). Analisa Hubungan Financial Literacy dan Demografi Dengan Investasi, Saving dan Konsumsi. Finesta, 3(1), 7-12.

Bandura, A. (1978). Self-efficacy: Toward a unifying theory of behavioral change. Advances in Behaviour Research and Therapy, 1(4), 139161. https://doi.org/10.1016/0146-6402(78)90002-4

Brandon, D. P., \& Smith, C. M. (2009). Prospective Teachers' Financial Knowledge and Teaching Self-Efficacy. Journal of Family Consumer Sciences Education, 27(1), 14-28.

Dwiastanti, A., \& Hidayat, W. (2016). Literasi Keuangan Ibu Rumah Tangga dalam Membentuk Perilaku Keuangan Keluarga. Prosiding SNA MK, $1-12$.

Haque, Abdul; Zulfiqar, M. (2016a). Women's Economic Empowerment through Financial Literacy, Financial Attitude and Financial Wellbeing. International Journal of Business and Social Science, 7(3), 78-88.

Haque, Abdul; Zulfiqar, M. (2016b). Women's Economic Empowerment through Financial Literacy, Financial Attitude and Financial Wellbeing. International Journal of Business and Social Science, 7(3), 78-88.

Hofstede, G. (2001). Hofstede, Geert - Culture's consequences_ comparing values, behaviors, institutions, and organizations across nations-SAGE (2001).pdf. sage publication. 
Hofstede, G. (2011). Dimensionalizing Cultures: The Hofstede Model in Context. Psychology and Culture, 2(1), 116-130. https://doi.org/10.1177/0305735616650994

Krishna, A., Rofaida, R., \& Sari, M. (2010). Analisis Tingkat Literasi Keuangan(Survey pada Mahasiswa Universitas Pendidikan Indonesia). Proceedings of The 4th International Conference on Teacher Education; Join Conference UPI \& UPSI Bandung, Indonesia, November, 552-560.

Kumar, S., Tomar, S., \& Verma, D. (2019a). Women's financial planning for retirement: Systematic literature review and future research agenda. International Journal of Bank Marketing, 37(1), 120-141. https://doi.org/10.1108/IJBM-08-2017-0165

Kumar, S., Tomar, S., \& Verma, D. (2019b). Women's financial planning for retirement: Systematic literature review and future research agenda. International Journal of Bank Marketing, 37(1), 120-141. https://doi.org/10.1108/lJBM-08-2017-0165

Lusardi, A., \& Mitchell, O. S. (2014). The economic importance of financial literacy: Theory and evidence. Journal of Economic Literature, 52(1), 5-44. https://doi.org/10.1257/jel.52.1.5

Lusardi, A., \& Mitchelli, O. (2007). Financial literacy and retirement preparedness: Evidence and implications for financial education. Business Economics, 42(1), 35-44. https://doi.org/10.2145/20070104

Margaretha, F., \& Pambudhi, R. A. (2015). Tingkat Literasi Keuangan Pada Mahasiswa S-1. Tingkat Literasi Keuangan Pada Mahasiswa S-1 Fakultas Ekonomi, 17(1), 76-85. https://doi.org/10.9744/jmk.17.1.76

Mustapha, M. (2015). Financial Literacy and Demographic Factors. Journal of Technology Management and Business, 2(1), 0-0.

Robb, C. A., \& Sharpe, D. L. (2009). Effect of personal financial knowledge on college students' credit card behavior. Journal of Financial Counseling and Planning, 20(1), 25-43.

Saadah, N. (2018). Perencanaan Keuangan Islam Sederhana dalam Bisnis E-Commerce pada Pengguna Online Shop. Economica: Jurnal Ekonomi Islam, 9(1), 105. https://doi.org/10.21580/economica.2018.9.1.2593

Sina, P. G. (2013). Financial Efficacy and Financial Satisfaction: Ditinjau dari Perbedaan Gender. Journal Manajemen Institute Transformasi Indoneis - NGO, 12(2), 173-184.

Widayat. (2010). Penentu Perilaku Berinvestasi. Ekonomika-Bisnis, 1(2), 111-128. 
Naili Saadah

Woodyard, A., \& Robb, C. (2012). Financial Knowledge and the Gender Gap. Journal of Financial Therapy, 3(1), 1-16. https://doi.org/10.4148/jft.v3i1.1453

JIEMB | 94 